\title{
MOVING WATERSHEDS, BORDERLESS MAPS, AND IMPERIAL GEOGRAPHY IN INDIA'S NORTHWESTERN HIMALAYA*
}

\author{
KYLE GARDNER \\ University of Chicago
}

\begin{abstract}
AB STRACT. This article uses the British colonial history of border making in northern India to examine the assumptions and contradictions at work in the theorizing, configuring, and mapping of frontiers and borders. It focuses, in particular, on the development of the 'water-parting principle'wherein the edge of a watershed is considered to be the border-and how this principle was used to determine boundaries in the northwestern Himalaya, a region that had long-established notions of border points, but no borderlines. By the twentieth century, the water-parting principle would become the dominant boundary logic for demarcating borders in mountainous regions, and would be employed by statesmen, treaty editors, and boundary commissioners around the world. But for the northwestern Himalaya, a region that British colonial officials considered to be the 'finest natural combination of boundary and barrier that exists in the world', making a border proved much more difficult than anticipated.
\end{abstract}

Precisely defined international borders are ubiquities of the modern world. So too are the maps that represent those borders, imbued with the signifiers of territory, sovereignty, and the nation-state. But while every border has a long and elusive pre-history, few have proven as indefinable as those found in the northwestern Himalaya, centred on the historical entrepôt of Ladakh. By the midnineteenth century, this region found itself increasingly close to the point where the empires of Britain, China, and Russia would meet. The mountainous northwestern Himalaya was ironically described, in the words of one British colonial frontier expert, as part of the 'finest natural combination of boundary and barrier that exists in the world'. But while the massive Himalayas

I 126 East 59th Street, Chicago, IL 6o637, USA kylegardner@uchicago.edu

* I would like to acknowledge the advice of Nick Abbott, Fredrik Albritton Jonsson, Amanda Blair, Daniel Haines, James Hevia, Elisabeth Leake, Zak Leonard, Thomas Simpson, Jesse Watson, Richard White, and the two anonymous reviewers of the original draft of this article. All of them provided insights and questions that substantially improved the final draft. All errors are my own.

1 Thomas Hungerford Holdich, Political frontier and boundary making (London, 1916), p. 280. 
('Himalaya' for the region) might have seemed like an ideal candidate to represent the solidified lines of British India's political borders, when India gained independence in 1947 the new republic inherited a largely borderless northern frontier. This borderlessness was not for lack of trying. Beginning in the 184 os and inspired by geographical principles espoused by Alexander von Humboldt, a century of surveys using ever more sophisticated technologies attempted again and again to define a border based on the idea of the limit of a watershed. These efforts yielded maps of staggering technological sophistication and personal daring which attempted to put nature to work for the imperial state. But the scientific precision of utilizing the watershed produced unintended complications, as it slowly became apparent that the edge of the Indus River watershed and the highest range of the northwestern Himalayas did not align. This geographical incongruity laid the groundwork for a conflict between the two most populous nations of the twenty-first century, over one of the least inhabited spaces on earth.

The causes of the long-running borderlessness in much of the Himalaya has long been ascribed by historians to 'top-down' diplomatic failures. ${ }^{2}$ Yet this approach overlooks the history of the changing practices and concepts used actually to produce borders. Historians interested in explaining the causes of the Sino-India War of 1962 pointed to the absence of a single accepted borderline between China and India. But they rarely questioned the problems produced by the geographical principles and practices that generated those lines in the first place. By the second half of the nineteenth century, colonial geography had organized the world into bounded territories often utilizing natural systems (river systems, mountain systems) as boundary-making objects. This view of systematized natural objects was reflected particularly in the development of the 'water-parting principle', wherein the edge of a watershed was used to establish a border. In the Himalaya, this principle was used to impose a borderline in a region that had only historically established notions of

${ }^{2}$ The 'top-down' focus of much of the historical scholarship on Himalayan borderlands reflected the need to understand why the world's two most populous nations went to war in 1962 over territorial claims at both ends of the Himalayas: the area in the eastern Himalaya now known as Arunachal Pradesh and in the northwestern Himalaya the virtually uninhabited Aksai Chin, a cold plateau roughly the size of Switzerland and situated almost entirely above ${ }_{15}$, ooo feet in elevation. Alastair Lamb's extensive writings offer in-depth detail about the geopolitical rivalries on British India's northern frontiers: Britain and Chinese Central Asia (London and New York, NY, 1960); The China-India border: the origins of the disputed boundaries (London, 1964); The Sino-Indian border in Ladakh (Canberra, 1973). Other works include G.J. Alder, British India's northern frontier I 865-1895: a study in imperial policy (London, 1963); Margaret W. Fisher, Leo E. Rose, and Robert A. Huttenback, Himalayan battleground: Sino-Indian rivalry in Ladakh (New York, NY, 1963); Dorothy Woodman, Himalayan frontiers: a political review of British, Chinese, Indian, and Russian rivalries (London, 1969); and Neville Maxwell, India's China war (New York, NY, 1970). 
border points. ${ }^{3}$ Colonial attempts to create a linear border also complicated the assumption that the highest mountain ranges and watersheds were coterminous. The apparently fixed 'water-parting' lines of the 'Indus watershed system' had a suspicious tendency to move. The development of these geographical border-making concepts also revealed contradictions within imperial frontier policy, particularly between the notion of natural frontiers and strategic ones. Despite these incongruities, by the twentieth century the water-parting principle became a key tenet of international boundary making around the world.

While historians have fruitfully explored the technological and political role of surveying and mapping in crafting colonial borders, few have examined the crucial geographical concepts resting beneath these border-making practices. 4 In focusing on the development of these practices and concepts, this article contributes to a diverse body of historical scholarship examining the nexus of imperial statecraft and science. 5 At the heart of border making was the deployment of geography in the service of the imperial state. As the sine qua non of territory, borders and their more abstract cousins, frontiers, became of existential importance to the empire. Frontiers were, as the viceroy George Curzon put it rather strangely in 1907 , 'the razor's edge on which hang suspended the modern issues of war or peace, of life or death to nations'. ${ }^{6}$

By examining the assumptions and contradictions at work in the theorizing, configuring, and mapping of frontiers and borders, this article delves into the geographical thinking that produced them. It also illustrates an example of

3 The use of border points was a sensible practice in a mountainous region where the limited number of routes into and out of the region functioned as effective points for the pre-colonial government to extract customs.

4 Matthew H. Edney's Mapping an empire perhaps comes closest, yet his work ends in 1843 , stopping short of the late Victorian period when boundary demarcation, mapping, and their connected underlying geographical propositions became increasingly important to the configuration of the imperial state. Matthew H. Edney, Mapping an empire: the geographical construction of British India, I 765-I 843 (Chicago, IL, 1997). Ian J. Barrow's Making history, drawing territory studies the Survey of India till 1905 and the end of Curzon's tenure as viceroy, a point often seen as the high-water mark of British imperialism in South Asia. Making history, drawing territory: British mapping in India, c. I756-I905 (New Delhi, 2003). Yet unlike Edney's focus on the cartographic construction of modern India, Barrow is more interested in how British imperial identity was shaped by the 'idea' of India. Other work that explores colonial surveying include D. Graham Burnett, Masters of all they surveyed: exploration, geography, and a British El Dorado (Chicago, IL, 200o); and Kapil Raj, Relocating modern science: circulation and the construction of knowledge in South Asia and Europe, I650-I90o (New York, NY, 2007).

5 On the broad literature between colonial knowledge, imperial statecraft, and technology, see Timothy Mitchell, Colonizing Egypt (Berkeley, CA, 1991); David Arnold, Colonizing the body (Berkeley, CA, 1993); C. A. Bayly, Empire and information (Cambridge, 1996); and, most recently, James Hevia, The imperial security state (Cambridge, 2012 ). For the concept of territoriality and its relation to practices of the state, see Charles Maier, 'Consigning the twentieth century to history: alternative narratives for the modern era', Forum Essay, American Historical Review, 105 (2000), pp. 807-31.

${ }^{6}$ George N. Curzon, Frontiers (Oxford, 19o8), p. 7. Taking Curzon's metaphor seriously, it is worth asking whether anything can actually 'hang suspended' on a razor. 
how imperial statecraft became tied to changing scientific practices and ideas. The development of the water-parting principle reveals how natural features were systematized and generalized for both cartographical and political ends. As this article will show, this process becomes visible through two inter-related developments. First, it was revealed through cartographical thinking-making maps that reflected both the concrete location and abstract representation of natural features. Mountains became more abstractly linear objects on maps, just as their dimensions were being more precisely recorded. Along with this transformation in cartography, tensions between ideas of natural and strategic frontiers began to reveal the increasingly intimate relationship between geography and the imperial state. This tension resulted in the repeated failure to craft a suitable border through the northwestern Himalaya in the century before Indian independence in 1947. These two different categories of frontiers - natural and strategic - were unified by the logic of the so-called 'scientific frontier'.7 The tension between natural and strategic frontiers was also illustrated by tensions between central colonial administrators, who desired maps that reflected broad strategic concerns, and frontier experts, who appreciated the technical requirements of boundary demarcation. Together, the scientific frontier and cartographical thinking reflected attempts to standardize colonial frontier practices and optimize the frontier's visibility to the colonial state, while also obscuring the often-uncertain terrain upon which they rested. By the mid-nineteenth century, this terrain was increasingly connected to the idea of the watershed, which emerged as a natural and political unit capable of being precisely surveyed, mapped, and utilized for border making. ${ }^{8}$

Although some scholars have viewed the surveying of British India as a triumph of state-sponsored scientific practice, this was not the case across much of the Himalaya.9 Rather, surveying was a slow and uneven process of attempting to stitch together distinct frontier segments, not only on increasingly restricted maps, but also under increasingly unified frontier policy. But a shift in policy does not always correlate with direct or consistent increases in information. This integration of frontiers was often conducted by central administrators at the central governmental level, often with the aid of maps that obscured their incomplete knowledge of those peripheral spaces (or else chose to represent

7 Ibid., p. 26.

8 This article draws inspiration from recent work by Bernard Debarbieux and Gilles Rudaz, which explored the ways in which mountains are socially constructed objects: The mountain: $a$ political history from the Enlightenment to the present (Chicago, IL, and London, 2015 ).

9 For the history of the ambiguities of the northeastern Himalayan frontier, see Bérénice Guyot-Réchard, Shadow states: India, China and the Himalayas, I9Io-1962 (Cambridge, 2017). For a comparative study of the failures of mid-nineteenth-century frontier-making in the northeastern and northwestern extremities of the British empire, see Thomas Simpson, 'Bordering and frontier-making in nineteenth-century British India', Historical Journal, $5^{8}(2015)$, pp. $5^{1} 3^{-42}$. 
their ignorance formally through the absence of borderlines). In defining imperial territorial limits, the British were also testing the limits of their geographical knowledge. But the repeated attempts by the British to configure a scientific frontier across northern India failed, in part because surveying revealed fluctuating locations for the Indus watershed and in part because political and military rationales for border locations changed in response to Russian and Chinese encroachment of India. These challenges to border making also reveal how the idea of the colonial state and its claimed territory often failed to overlap neatly.

This incongruity often stemmed from maps and their political use. One of the great hidden powers of maps is their capacity to obscure the processes and 'propositional logic' that produced them, particularly the assumptions and conventions that simplify, obscure, or enhance the natural features used to define territory. ${ }^{10}$ As advances in surveying techniques yielded maps with greater degrees of detail, maps came to hold more political authority. But despite recent critical interventions in the history of cartography, maps were 'technologies of power' only insofar as they could achieve the state's desired degree of territorial legibility. ${ }^{11}$ The cartographic ability (or inability) to represent territory - whether state-controlled territories like Kashmir or Arunachal Pradesh, or uncontrolled (or at least ungoverned) territories like the many (now former) enclaves of the Indo-Bangladeshi borderlands - symbolized how the threat of 'non-state space' erodes 'territorial inviolability', in Willem van Schendel's words. ${ }^{12}$

This notion of territorial inviolability emerged coevally with territorial legibility - at least in the abstract form presented by authoritative maps. In other words, the clearer the territory appeared on the map, the greater the assertion of political control (or the need for political control). By the end of the nineteenth century, terra incognita had almost completely disappeared. As the world became mapped, a theory emerged that conceived of the entire globe as constituted by a set of geographical determined, interdependent parts. This became known as 'geopolitics'. Coined in 1899 by Rudolf Kjellén to reflect an approach to international politics that emphasized territory and geographical information in forming and sustaining states, the portmanteau reflected interconnected trends in geography and imperial state formation decades in the making. ${ }^{13}$

${ }^{10}$ Denis Wood and John Fels, The natures of maps: cartographic constructions of the natural world (Chicago, IL, and London, 2008), p. 26.

${ }^{11}$ J. B. Harley, 'Deconstructing the map', in Trevor Barnes and Derek Gregory, eds., Reading human geography: the poetics and politics of inquiry (London, 1997), p. 164; Denis Wood, The power of maps (New York, NY, 1992); and James C. Scott, Seeing like a state (New Haven, CT, 1999).

12 Willem van Schendel, 'Stateless in South Asia: the making of the India-Bangladesh enclaves', Journal of Asian Studies, 61 (2002), pp. $115^{-47}$.

13 The term 'geopolitics' signalled a new approach to international politics, one that emphasized territory, natural resources, and geographical information in forming and sustaining states. John Agnew, Geopolitics: re-visioning world politics (London and New York, NY, 1998); and Brian Blouet, Geopolitics and globalization in the twentieth century (London, 2010), p. 187 n. 2. 
The intimate relationship between geography and state was reflected in publications such as the Geographical Journal of the Royal Geographical Society, which provided a forum for recent discoveries, evolving surveying technologies, new maps, and newly discovered routes across imperial frontiers. Crucially, it also provided a platform for former imperial frontier experts, such as Thomas Holdich, and scholars, such as Oxford's first Professor of Geography, Halford Mackinder, to articulate theories of geography's determining effect on human societies and states. ${ }^{14}$ Geographical science had become political science. And watersheds had become political instruments.

This article begins with a brief history of the idea of the watershed, which grew out of earlier notions of water and mountain systems, Humboldtian geography, and international legal theory. It then explores the first British boundary commissions ( 1846 to 1848 ) in the northwestern Himalaya and their employment of the 'water-parting principle', which would form the basis of increasingly authoritative and restricted trans-frontier maps. The third section shifts to the 1870 os and 188 os, when revisions to the initial demarcation attempts asserted that the 'Indus watershed system' should be the natural boundary of northern India. This watershed system was understood by late nineteenth-century colonial administrators, and international legal theorists, statesmen, and surveyors around the world, to be the land through which the Indus and its tributaries drained, up to the water-parting ranges that separated the Indus from its neighbouring watershed systems. However, the application of these principles also reflected tensions between the surveyors, who sought to identify natural markers to map, and administrators, who appreciated the elegance of a single boundary principle even if its mapped reality failed to correspond to a line on the ground. The article concludes by showing how the production of borderless maps up to 1947 was the result of the continued insistence on the waterparting principle and the assumed authority of earlier survey maps of the region. The eventual omission of a northwestern Himalayan boundary line on successive Survey of India maps was not simply the result of a diplomatic failure to determine an acceptable international border: it was the result of competing and contradictory ideas about how best to use natural features as a means to achieve political ends.

\section{I}

Bodies of water have long served as regional demarcators. The significance of the hydrographical networks of the Indus and Ganges are well documented in the major texts of pre-colonial India, from ancient Sanskrit Ayurvedic texts

${ }^{14}$ Halford Mackinder presented to the Royal Geographical Society on 25 January 1904 his influential paper, 'The geographical pivot of history', which was subsequently published in the Geographical Journal. H. J. Mackinder, 'The geographical pivot of history', Geographical Journal, 23 (1904), pp. 421-37. 
to the Mughal Akbarnama. In his Ai'n-i-Akbari ('The regulations of Akbar'), Emperor Akbar's vizier Abu'l Fazl 'Allami (1551-1602) described Hindustan as a land bordered by oceans, including the mountains separating the Mughal territories from Central Asia and Tibet. Water - actual and metaphorical - has deep historical roots in shaping definitions of territory, and serving as natural boundaries. Yet water was never fixed. As understandings of water's nature changed, so too did boundaries.

In the European colonial context, connected bodies of water (rivers, lakes, and bays) have been associated with territorial claims since at least the seventeenth century. ${ }^{15}$ But only in the eighteenth and early nineteenth centuries did the study of water and earth systems become increasingly schematized within the study of geography and geology. In the minds of political actors, these systemic visions of the natural world combined with older notions of mountains and rivers as boundaries to manifest in the political utilization of so-called 'natural divisions' that marked the edges of territories. While mountains had long been natural dividers, the combination of mountains and water to form 'water-partings' was a product of eighteenth-century knowledge formation and colonial claims to territories first in North America and later elsewhere across the globe. ${ }^{16}$ The increased frequency of river exploration that accompanied European imperial expansion also enhanced the political importance of waterways as simultaneous conduits and potential boundaries. ${ }^{17}$

Alexander von Humboldt $(1769-1859)$ was one of the earliest modern geographers whose theories were regularly employed by political actors. Humboldt combined growing understandings of water networks and mountain ranges with the increased authority of maps. Humboldt sought to establish general principles by which accurately defining and visually rendering the world's regions would lead to better understanding of the 'unity of nature' - the deep and intimate connections that exist between the branches of science and between human society and its varied environments. Like Montesquieu and others before him, Humboldt also sought to explain human culture through the lens of climate. Colonial explorers, boundary commissioners, and legal jurists all regularly cited Humboldt. ${ }^{8}$ Critically, Humboldt's work followed several decades of notable advances in the expanding fields of geography, geology, and cartography, each of which also exerted increased political influence. Through the medium of maps in particular, watersheds emerged as territorial objects assembling systems of mountains, valleys, plains, and bodies of water.

\footnotetext{
15 See, for instance, the Royal Charter of the Hudson's Bay Company, accessed on 1 July 2015 : www.hbcheritage.ca/hbcheritage/collections/archival/charter/charter.asp.

${ }^{16}$ On the role of mountains in shaping early modern borders, see Peter Sahlins, Boundaries: the making of France and Spain in the Pyrenees (Berkeley, CA, 1989); and Debarbieux and Rudaz, The Mountain.

17 See, for example, Noboru Ishikawa, Between frontiers: nation and identity in a Southeast Asian borderland (Athens, OH, 2010).

18 Burnett, Masters of all they surveyed, p. 15.
} 
By the 1840 , European and American legal scholars were citing Humboldt's writings, suggestive of his widespread influence as well as the ex post facto colonial concern with legal justification for territorial conquest and demarcation. The prominent English jurist, Sir Travers Twiss (1809-1897), writing about legal disputes over the Oregon territory, frequently utilized examples from Humboldt's Political essay on the kingdom of New Spain (1811) - a geographical and cartographical description of Mexico. In his The Oregon question examined (1846), Twiss employed Humboldt's work to articulate a theory of discovery. ${ }^{19}$ Twiss concluded that according to 'the acknowledged law and usage of nations', claimant nations like Britain and the US had 'a right to the whole country drained by that river and its tributary streams'. ${ }^{20}$ This type of claim departed from previous riparian principles articulated by international legal theorists like Emer de

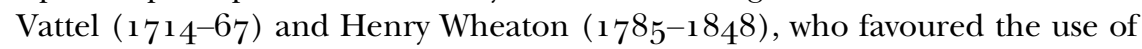
rivers as boundaries. ${ }^{21}$ However, it became increasingly apparent to colonial officials that rivers rarely divided politically distinct peoples, as the viceroy George Curzon would later note in his discussion of the history of natural frontiers in 1907 . In his words, a river was a better 'means of access to a country than a line of division between races', a category of increasing importance to the definition of nations. ${ }^{22}$ By the second half of the nineteenth century, the term 'watershed' was regularly invoked to assert a principle of territorial organization and border making. ${ }^{23}$

Foremost among Humboldt's observations on the great mountain systems of the world was the strong tendency towards 'parallelism' - that is, the tendency of mountains to form in linear, parallel chains. The Himalayan boundary commissioner Alexander Cunningham remarked in his Ladak (1854) that 'The general parallelism of the principal mountain-ranges of the world - of the Himalayas and the Altai, in Asia - of the Atlas, in Africa - and of the Alps and Apennines, the Pyrenees and Carpathians, in Europe-has already been noticed by Humboldt and others.' 24 But Humboldt also acknowledged a crucial divide within the Himalaya and the Tibetan plateau, thanks largely to the writings of the explorer William Moorcroft and other scientific travellers' accounts published in the Transactions of the Royal Asiatic Society of Great Britain and Ireland and the Journal of the Royal Geographical Society of London.

19 Travers Twiss, The Oregon question examined, in respect to the facts and the law of nations (London, 1846).

20 Ibid., pp. $14^{8-9}$.

${ }^{21}$ Emer de Vattel, Droit des gens; ou, Principes de la loi naturelle appliqués à la conduite et aux affaires des nations et des souverains (1758); and Henry Wheaton, Elements of international law $\left(183^{6}\right)$.

${ }^{22}$ Curzon, Frontiers, p. 12.

23 See, for instance, Legislative Assembly, The proceedings before the Judicial Committee of Her Majesty's Imperial Privy Council on the special case respecting the westerly boundary of Ontario... (Toronto, ON, 1899).

${ }^{24}$ Alexander Cunningham, Ladák, physical, statistical, and historical; with notices of the surrounding countries (London, 1854 ), p. 42. 
Humboldt wrote that east of the sacred lakes of Manasarovar and Rakshastal in Western Tibet there was a 'transverse uprising'25 that signalled the 'waterparting' ('formant le partage d'eau (divortia aquarum) à l'est des lacs sacrés') between the Indus and the Yarlung Tsangpo/Brahmaputra, the origins of which still remained a mystery to these geographers. While he stops short of using the term 'watershed', Humboldt's insistence on the waterparting as a key object of dividing natural units of land reflected a shift in geographical thinking towards a territorial unit that could be determined by combining water and mountain systems through the medium of the map. A century later, the water-parting principle would be an established ideal in international border making. Applying this principle, however, required surveyors first to locate the water-parting line.

\section{I}

By the time of the establishment of the two Himalayan boundary commissions in 1846 to 1848 , the British had already presided over a violent and rapid territorial expansion that required extensive definition of its limits. In many places throughout Britain's South Asian empire, historical boundaries were readily adopted, particularly those districts that utilized older political divisions from the Mughal period. But in places where boundaries were unknown or unsatisfactory, commissioners frequently resorted to utilizing nearby rivers and streams. The 'Thalweg Principle' - measuring a boundary from the lowest point of a riverbed - was frequently used in relatively flat riverine regions, such as the Indo-Nepalese plains. Rivers, however, proved less than ideal boundary markers because, to quote a British Resident in Kathmandu, Charles Girdlestone, 'their tortuous, shifting and erratic character' made them less suitable than boundary pillars and mountain peaks, which formed 'straight lines from conspicuous point to point'. ${ }^{26}$ Straight lines, unlike 'erratic' rivers, are rarely found in nature, but they work very well on maps.

Boundary pillars were often used in the plains, allowing for precise geodetic points to be determined and plotted on maps. 'Should the boundary marks themselves vanish', the frontier expert Thomas Holdich noted, 'there should always remain a record of their position on the map, and a repetition of the same survey process will show precisely where the original site may have been.' 27 But it was the water-parting principle that gained pre-eminence in the mountainous frontiers and would, by century's end, be the undisputed ideal of boundary demarcation. 'The best and most recognizable natural

25 That is, a mountain range running perpendicular to the main axis of the Himalayas.

${ }^{26}$ National Archives of India (NAI), Foreign Department (Foreign), A Pol E, $187-96$, May 83 , 'Alluvial streams (Nipal). Permanent land line boundaries to be adopted in supersession of boundaries.'

${ }^{27}$ NAI, Foreign, Secret, no. 41, Oct. 1896. 
boundary', noted Holdich, 'is a well-defined watershed.' ${ }^{28}$ By 1945, the waterparting principle had become a key tenet of international boundary making. In his Boundary-making: a handbook for statesmen, treaty editors and boundary commissioners, the American geographer Stephen B. Jones noted that 'The virtues of waterparting [sic] boundaries are that...they are precise and unique and that they separate drainage basins, which for many purposes are best treated as units under a single government.'29 The development of this international border-making principle reflected a transformation in how borders were conceived of and represented.

Unlike borderlines, the general acceptance of border points had long existed in the Himalayan region. Typically located on established trade and pilgrimage routes, these points served as means for signalling seasonal customs duties to be paid, or corvée labour to be given for the triennial trade mission to Lhasa and the biennial reciprocal mission from Lhasa established by the 1684 Treaty of Tingmosgang (the lo.phyag and gzhung.tshong, respectively). $3^{\circ}$ These border points acknowledged the transition of jurisdictions at the edges of populated regions. Most of the region to the north and east of Ladakh - now generally referred to as the Aksai Chin-had no permanent population, though traders, pilgrims, and semi-nomadic herders regularly traversed it. While rarely explicitly referenced in indigenous accounts, these border points continued to function as political markers for centuries.

In 1842 , eight years after the Dogra-led invasion of Ladakh, representatives of the Dogra Raja of Jammu, $3^{1}$ the emperor of China, and the Dalai Lama signed a treaty that reaffirmed the 'boundaries of Ladakh and its surroundings as fixed from ancient times', though without acknowledging the location of those boundaries. ${ }^{2}$ Four years later, the first British boundary commission arrived to survey its newly acquired dependent princely state, Jammu and Kashmir.

In 1846 , the East India Company's governor general, Henry Hardinge, appointed two successive commissions to determine a permanent boundary in the northwestern Himalaya, on the easternmost edge of the newly conjoined

28 Ibid.

29 Stephen B. Jones, Boundary-making: a handbook for statesmen, treaty editors and boundary commissioners (Washington, DC, 1945), pp. 101-2.

$3^{\circ}$ See John Bray, 'Corvée transport labour in nineteenth- and early twentieth-century Ladakh: a study in continuity and change', in Martijn van Beek and Fernanda Pirie, eds., Modern Ladakh: anthropological perspectives on continuity and change (Leiden, 2008), pp. 43-66.

$3^{1}$ The northern principality of Jammu, ruled by a dynasty of Dogra Rajputs, was a tributary of the Sikh empire after its conquest and eventual annexation by the Sikhs in 1816 . Gulab Singh, the Raja of Jammu (1822-57), invaded Ladakh at the likely behest of the Sikh emperor Ranjit Singh in 1834 to secure access to the high-value pashmina trade routes threatened by British expansion further south. Following the defeat of the Sikh empire in the first Anglo-Sikh war of 1845 to 1846 , the East India Company granted Gulab Singh, who tacitly assisted them during the war, the title of maharaja of Kashmir and Jammu, thus inaugurating the Dogra dynasty that would rule the princely state of Kashmir and Jammu until 1947.

$3^{2}$ J\&K State Archives, Jammu, 'Treaty between Ladakh and Tibet: 1920, 276/R.P-4'. 
and politically subordinate state of Kashmir and Jammu. The commissions comprised the future founder of the Archaeological Survey of India, Alexander Cunningham, and a celebrated Himalayan explorer, Henry Strachey. It also involved a botanist, Thomas Thomson, whose inclusion reflected the growing practice of including natural scientists as members of boundary commissions. The governor general wanted a 'clear and well defined boundary [that would] prevent the possibility of dispute'.33 The commissioners were told by those in charge to seek out as boundaries 'such mountain ranges as form water-shed lines between the drainages of different rivers'. For their published contributions to the study of Himalayan geography, both Strachey and Thomson would receive the Royal Geographical Society's highest prizes.

When the British requested that the Qing government send representatives to the northwestern Himalaya to demarcate jointly a border between the two empires in 1846, the governor general of Liang-Guang, Qiying, refused. Qiying cited a long historical understanding of the boundary, reaffirmed in an 1842 treaty, which could be traced back to at least the seventeenth century and the Treaty of Tingmosgang.

Once the British determined that no Chinese boundary commissioners would participate in the demarcation, the three boundary commissioners, Cunningham, Strachey, and Thomson, were given orders to begin, thus establishing the precedent for unilateral boundary making in the region that would continue for more than a century. ${ }^{4}$ Again, the commissioners were given instructions to make use of the region's natural features for the purposes of deriving a paper boundary:

Boundary marks are neither requisite nor probably possible, you will find plenty of mountains ready to your hand. And these natural pillars should not only be carefully mapped for registry with the British Government, but their appearance and bearings should be fully and distinctly recorded in writing, and a copy furnished to the representations of each of the three contracting parties. The experience acquired in your last trip should enable you to accommodate your route to the seasons, i.e. to finish your work in the higher tracts before snow falls and cuts off your retreat. 35

The botanist Thomas Thomson set about testing Humboldt's general principles. The whole of the Tibet', he wrote, 'appears to be characterized by great uniformity of climate and productions and perhaps also of natural features, on which account it appears convenient to retain the name for the whole country,... as has already been pointed out by Baron Humboldt, is naturally separable into two grand divisions.' ${ }^{6} 6$ The first of these was the watershed of the

33 NAI, Foreign, nos. 162-4, 28 Aug. 1847, 'Instructions for his guidance on his approaching mission to the Thibetan frontier'.

34 Ibid.

35 Ibid.

$3^{6}$ NAI, Foreign, 29 Dec. 1849, pp. 332-4, F. C., 'Thomson, Asstt.-Surgeon T. Report on Western Thibet'. 
Tsangpo, which in India becomes the Brahmaputra, and the second was the Indus.

But Thomson also began to see complications. In his report to the East India Company, he noted that if all of Western Tibet were a single, 'extensive plain bounded on the South by the great chain of the Himalaya and on the north by the lofty mountains of Kunenlun [sic] it would be an easy task to define its boundaries'.37 However, in reality, he noted:

A line of high snowy peaks may doubtless be traced in a direction nearly parallel to the plains of India, but these are separated from one another by deep ravines along which flow large and rapid rivers, and therefore afford no tangible line of demarcation between the two countries. Between the river Indus and the plains of N.W. India is interposed a mountain tract which has a breadth of about $15^{0}$ miles in line as distance. $3^{8}$

Thomson thus acknowledged that the geographical reality of the supposedly systemic, parallel Himalayas was much more complicated than had earlier been assumed, and that deriving a clear, natural line of demarcation was no simple task. This complication also highlighted a critical topographical irony of much of the history of surveying in the region. The Himalaya was long seen as a barrier - what the poet Muhammad Iqbal would later call the 'dīwār-iHindustān' ('wall of India') - that separated India from the land beyond. But, as most topographical maps drawn since 1800 illustrate, Ladakh is beyond, or within, that 'wall'. When Thomson wrote of a mountain tract $15^{\mathrm{O}}$ miles wide, he effectively acknowledged that Britain's frontiers could not end at a clear wall of mountains, but potentially stretched somewhere deep within them. But Thomson also recognized that the main rivers running through this complex of mountains could offer a means of resolving this topographical tangle. 'If [the rivers] be taken as a guide, the mountains will be found to resolve themselves into two great systems, connected to the eastward but otherwise independent of, though nearly parallel to one another.' Thus, the watersheds of the Indus and the Tsangpo/Brahmaputra became two central objects of demarcation. The 'Indus watershed system', as it came to be known, would soon become the understood frontier of northern India.

The maps generated by the second commission satisfied colonial officials in charge, asserting that a natural boundary had been found and that a principle had been established. But more pressing problems of governance drew the attention of the East India Company back to the plains of India.

\section{I I}

The rebellion of $1857-8$ marks a critical moment in South Asia's political history. In the face of widespread violence, political upheaval, and brutal

37 Ibid.

$3^{8}$ Ibid. My emphasis. 
retribution, problems pertaining to mapping mountains and rivers at the edges of the empire became a decidedly peripheral concern. But as the British refashioned their rule of the subcontinent in the wake of internal rebellion, they also grew alarmed by the external threats posed by the approach of the Russian and Chinese empires to their still vague northern frontiers. From this moment forward, security suffused all political and commercial considerations for British administrators in India - and increasingly guided the production of maps. As the government of India grew increasingly alarmed by Russian encroachment, more precise techniques and extensive boundary commissions were established to detail India's frontier, which became an increasingly restricted and 'classified' space.

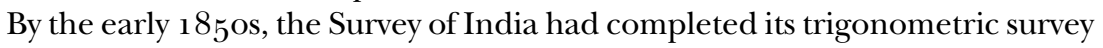
from its base in Dehra Dun up to the northwestern town of Peshawar, thus enmeshing their empire in a triangulated grid of precisely measured and mappable spatial points. The Survey's mapping of Kashmir began in 1854 and recommenced in 1858 , utilizing the more precise trigonometric technique employing a theodolite that had become standard for Survey of India maps. 39 The results were a series of detailed maps of the region in 1859 and 1861 . Owing to altitude, its vastness, and the harshness of climate, Ladakh was not surveyed in the same way when mapping recommenced there in the 1860 s. Instead, it was primarily mapped by 'traverse' survey - sketched maps based on measured distances on the ground - akin to the method of the 1846 to 1848 boundary commissions.

In 1865 , William Johnson made a north-south traverse of the easternmost trade route between Yarkand and Leh. But owing to his traverse survey, he did not triangulate the distances to, and heights of, the mountains and hills scattered to the east of the barren plateau he crossed. The resulting map was published in 1868 . Johnson would later become the Dogra-appointed waz̄ir-i-wizârat ('district administrator') of Ladakh. His survey of the region, and the eventual 'line' of mountains it produced, remained the basic cartographical representation for the remainder of the nineteenth century. It endures as one of the main sources for India's continued claims to the Aksai Chin today. $4^{\circ}$ Critically, however, Johnson did not survey the mountains that formed the supposed outer perimeter of the Aksai Chin and a possible edge of the Indus watershed. Given the paucity of snowfall on the arid, largely glacier-less plateau, determining water partings was a nearly impossible task.

British interest in commercial ventures in Central Asia, coupled with growing concerns about the Russian empire looming large from the north, pushed the Survey of India to produce more detailed maps of 'trans-frontier' regions representations of the limits of British territory, however vaguely defined it

39 For a description of this surveying process by the large boundary commissions and surveying parties of the late nineteenth century, see Hevia, Imperial security state, pp. 73-1o6.

$4^{\circ}$ Lamb, The Sino-Indian border in Ladakh, pp. 8-9. 
may be. However, political uncertainties and the occasional unfriendly welcome in regions beyond British territories forced the Survey to do so more covertly, often with the aid of trained Indians, known as pundits.

The pundits - often from the hills but sometimes from Bengal or other plains areas - were trained by the Survey of India to take part in covert intelligencegathering missions beyond the borders of India. Often disguised as pilgrims or traders, these agents were equipped with an array of hidden instruments to facilitate their work-practices made famous by Kipling's portrayal of Anglo-Russian Himalayan intrigue in Kim (1901). These highly praised 'human instruments' - as Kapil Raj has styled them - formed a hybrid colonial scientific practice of colonizers and colonized..$^{1}$ The maps that the pundits and other Indian surveyors produced served to fill in the blank trans-frontier spaces on the Survey of India's maps. They also made it even clearer to central administrators that the government of India needed more precise demarcations of the frontier. Regarding the earlier 1846 to 1848 boundary commissions in Ladakh, for instance, the resulting 'information and the maps [were] so conflicting, that it [was] impossible to say what was the boundary'. $4^{2}$ Due to the conflicting maps, the government of India determined that a new boundary commission should ignore the 1846 to 1848 boundary and that 'the whole question should be reinvestigated de novo'. Therefore, in the 1870 , renewed attempts were made to determine Ladakh's boundaries, again applying the water-parting principle. 43 'To fix the boundary on the permanent water-shed', wrote the secretary to the government of the Punjab to the foreign secretary, is 'to act on a clear and distinct principle'.44

By the early 1870 , the government of India's Foreign Department indexes show a significant spike in boundary commissions, a trend that would only accelerate until the turn of the century. This new wave of attempts at border demarcation came in part because earlier commissions, like those in the northwestern Himalaya, were based on technically deficient 'traverse' surveys that produced inaccurate maps. It was also the result of an increasingly scientific approach to boundary settlement, one where teams of surveyors, naturalists, and boundary experts, like the aforementioned Thomas Holdich, would systematically 'lay down' a borderline by way of standardized practices centred on identifying natural markers, or creating them (i.e. producing boundary pillars), when necessary. Experts like Holdich represented a new generation of frontier experts who employed the latest precision surveying instruments to generate an increasingly detailed accounting of imperial territory. Most of the major

$4^{1}$ Kapil Raj, Relocating modern science.

$4^{2}$ NAI, Foreign, Political A, nos. 240-1A, May 1870, 'Boundary between Cashmere and Lingti'.

43 NAI, Foreign, Political A, nos. 10-12, May 1872, 'Boundary between Spiti and Ladakh'; and NAI, Foreign, Political A, nos. 203-6, Jan. 1873, 'Settlement of the Spiti and Ladakh boundary'.

44 NAI, Foreign, Political A, May 1873, nos. 10-12. 
bilateral boundary commissions - the Anglo-Russian Afghan Boundary Commission, the Anglo-Russian Pamir Boundary Commission, and the SinoBritish Burma Boundary Commission - succeeded in producing highly detailed demarcated borders, even if these borders were often ignored locally. But the northwestern Himalaya, like the northeastern Himalaya would later prove, was a different case. The high altitude, inhospitable climate, and difficulty in determining a legible water-parting line in the Aksai Chin together produced a series of hypothetical border configurations. While those who attempted to survey parts of it fretted about the lack of geographical information available, imperial administrators were more concerned with eliminating 'no-man's lands' like the Aksai Chin, which represented a threatening and incongruent 'nonstate space'. 45

In 1879 , the then-viceroy, Lord Lytton, articulated the first general frontier policy for northern India - a policy with roots going back beyond the first Himalayan boundary commissions. 'The natural boundary of India', he wrote,

is formed by the convergence of the great mountain ranges of the Himalayas and of the Hindu Kush... [If] we resolve that no foreign interference can be permitted on this side of the mountains, or within the drainage system of the Indus, we shall have laid down a natural line of frontier which is distinct, intelligible, and likely to be respected. $4^{6}$

As the spectre of Russian and Chinese advances in Central Asia provoked deepening anxieties in Calcutta, Shimla, and London, more resources were spent on surveying and demarcating the northern and eastern edges of Kashmir. These projects became covert, classified, and militarized. In 1876, Captain Henry Trotter made a trans-Himalayan survey and produced a map, fragments of which ended up in several Indian newspapers. The government reacted angrily to this. As a result, reports on trans-frontier survey operations were subsequently deemed 'strictly confidential'.47 In 1884, the government of India ordered that notifications of boundary demarcations were not to appear in the Gazette of India. $4^{8}$ Access to trans-frontier maps was formally restricted in 1885. ${ }^{49}$ And regular frontier intelligence gathering became routine, organized through the recently formed Intelligence Branch that played a critical role in operations on the Afghan frontier. $5^{\circ}$

45 James C. Scott, The art of not being governed: an anarchist history of upland Southeast Asia (New Haven, CT, and London, 2009), pp. 10-11.

$4^{6}$ India Office Records, Political and Secret, letters and enclosures from India, vol. 21 , no. 49, 28 Feb. 1879 .

47 Captain Henry Trotter, Account of the survey operations in connection with the mission to Yarkand and Kashghar in $1873-74 \ldots$ (Calcutta, 1875).

$4^{8}$ NAI, Foreign, A Political E, nos. 201-2, June 1884.

49 NAI, Foreign, Secret F, nos. 1-3, Nov. 1885, 'Trans-frontier information. Publication of frontier maps containing only sketchy survey(s) permitted'.

$5^{\circ}$ For a history of the Intelligence Branch, see James Hevia, Imperial security state. 
In 1888, Captain Henry Ramsay, the British joint commissioner at Ladakh, wrote to his superiors in the government of India's Foreign Department urging them to consider defining the boundaries in northern and eastern Kashmir once again..$^{1}$ His predecessor, Ney Elias, now a frontier expert whose advice would be sought by the government of India on frontiers from Afghanistan to Siam, responded that he believed that 'complete surveys [had] long ago been made by the regular survey of India, of all the country up to limits of the Indus system watershed'.52 But after much back and forth with the Foreign Department, officials concluded that the available maps (the Johnson map of $186_{5}$, in particular) did not inspire much confidence in the exact location of the Indus watershed, thus calling into question their conception of the northern frontier. While much of the subcontinent was mapped with the precision of trigonometric surveys, the difficult terrain of the Aksai Chin and the sketchy traverse surveys of Johnson and the pundits did not allow for a satisfactorily whole cartographic image upon which to demarcate a complete borderline.

The British Resident in Kashmir wrote to the foreign secretary of India, Mortimer Durand, that he was of the 'opinion that the adjustment of the whole northern and north-western frontier of Kashmir should not be further postponed'. He continued,

The recent development of Imperial policy and the measures taken within the last three or four years to secure against attack or surprise routes leading from Central Asia or Afghanistan to India make it, I think, undesirable longer to defer the settlement of this boundary...I would advise that some officer...should be sent early this year confidentially and quite quietly,...accompanied with two or three clever mappers to work out on the spot the best scientific frontier to include the most inaccessible portions...Scientific accuracy need not be prescribed as so essential relatively as military features, and in this way I hope the Government of India would within the present year, be furnished with a valuable report, showing the best scientific boundary for the north and north-western frontier of Kashmir. Thus the work of a future delimitation commission would be rendered comparatively simple. 53

A scientific frontier, as defined in 1907 by the former viceroy, George Curzon, was 'a Frontier which unites natural and strategical strength'.54 The period term 'scientific' reflected a process of merging precise geographical information with military or political strategy and revealed the development of geopolitics as an analytic frame derived from the premise that geography was a determining factor in the success or failure of states. And frontiers were 'the

\footnotetext{
$5^{1}$ NAI, Foreign, Secret Frontier, Mar. 1889, nos. $115^{-16}$, 'Frontier between Ladakh and Chinese-Turkestan'.

$5^{2}$ Ibid.

53 Ibid. My emphasis.

54 Curzon, Frontiers, p. 26.
} 
razor's edge' upon which the 'life or death' of nations rested.55 The strategic aspect of frontiers could shift alongside the geopolitical fluctuations of imperial politics. As maps came to include greater technical detail, they often retained symbolic references to early renderings of solid, parallel mountain ranges that made for the appearance of a concrete and legible border. But the certainty of solid lines on large-scale maps - and the geographical principles upon which they apparently rested - continued to belie deeper uncertainties on the ground.

The water-parting principle, which in theory had previously offered such a clear means of removing any disputes, became increasingly difficult to apply on the ground. Curzon remarked on this in his 1907 Oxford lecture on frontiers.

In every mountain border, where the entire mountainous belt does not fall under the control of a single Power, the crest or water-divide is the best and fairest line of division; for it is not exposed to physical change, it is always capable of identification, and no instruments are required to fix it..$^{6}$

But this 'fairest line' was itself not always clear. Curzon went on to note 'the wellknown geographical fact that in the greatest mountain systems of the world, for instance, the Himalayas and the Andes, the water-divide is not identical with the highest crest, but is beyond it and at a lower elevation' .57 By this time, Curzon's was hardly an original observation.

This inconvenient geological situation - which had been remarked on by Strachey in his 1854 Physical geography of Western Tibet-provoked heated debates in the highest echelons of the imperial government. The War Office's director of military intelligence, John Ardagh - with an eye to the tactical advantages of keeping potential enemies off the high ground - advocated refraining from more precise demarcation in the Karakoram in the hopes of coaxing China into the expansive lower terrain of Kashgaria and the Tarim Basin while retaining effective occupation of the glacial high ground. $5^{8}$ Strategically speaking, Ardagh wanted the Chinese to occupy the vast and inhospitable western Tarim Basin in order to prevent Russia from surreptitiously taking over that no-man's land. But this departed from the water-parting principle insofar as it gave up what was then believed to be the northeastern reaches of the Indus watershed.

Throughout the last three decades of the nineteenth century, military and civilian strategists struggled to agree where the strategic or natural frontiers would lie. Military advisors appreciated keeping potential enemies off the high ground, but that conflicted with the natural water-parting principle,

55 Ibid., p. 7.

$5^{6}$ Ibid., p. 19 .

57 Ibid., pp. 19-20.

$5^{8}$ NAI, Foreign, Secret F., Nov., nos. 110-14, 'Kashmir-Frontier. Memorandum by Sir John Ardagh'. 
which offered both sides - theoretically at least - access to the heights. Civilian administrators tended to favour the less stringent amalgamation of boundary pillars, bodies of water, and mountains ridges that reduced the range of territory to govern. By 1890 , a vague strategy was reached. 'The Government have now decided that, for the present at any rate, the limits of the Indus watershed should be considered as the boundary of the Kashmir territories to the north, and that the line of natural water-parting...should be regarded as the limit of our political jurisdiction.' 59 In other words, the political line that marked the northern edge of India would be coterminous with the limit of the Indus watershed. In choosing this model, military logic co-existed with the indeterminacy of the often un-demarcated watershed limits. But given the dearth of trigonometric-based survey maps of the northern and eastern edges of Ladakh, the Survey of India was obliged to rely on the sketchier shapes of a handful of traverse surveys when representing the limit of the watershed. The result was the production of two kinds of maps: those that showed a border that relied on a handful of precise points and a speculative line representing a suggested water-parting, and those maps that showed no borders at all.

On 14 March 1899 , this ambiguous arrangement was formalized in a memorandum sent to the Qing government by Claude MacDonald, the British minster at Peking. Echoing the East India Company's language to the 1846 to 1848 boundary commissioners, MacDonald wrote to the Zongli Yamen ${ }^{60}$ that it was now proposed 'that for the sake of avoiding any dispute or uncertainty in the future, a clear understanding should be come to with the Chinese government as to the frontier between the two States'. Yet the memo also went on to assert that 'it will not be necessary to mark out the frontier... The natural frontier is the crest of a range of mighty mountains, a great part of which is quite inaccessible.' It was sufficient from the British perspective to outline the prominent features of the Indus watershed in the memo, and to cite this line described on a map of the 'Russo-Chinese frontier brought by the late Minister, Hung Chun, from St. Petersburg, and in possession of the Yamen'. ${ }^{61}$ The vague description in the letter, which continues to generate much debate between India and China, suggested a line that largely followed what the British understood to be Indus watershed limit, though they did not have a satisfactory map to represent the whole region beyond just the RussoChinese frontier. ${ }^{62}$

When Fanny Bullock Workman and her husband, Dr Hunter Workman, requested permission from the government of India in 1912 to survey the Siachen glacier in the Karakoram, north of Ladakh, their expedition was

59 Ibid.

6o China's Foreign Affairs body established in 1861 and replaced with a ministerial Foreign Office in 1901.

${ }^{61}$ NAI, Foreign, Secret F, Aug. 1899, nos. 168-201. There is no known surviving version of this map.

62 Lamb, Sino-Indian border in Ladakh, p. 7 . 
given approval contingent on the inclusion of a Survey of India surveyor. The secretary to the Foreign Department, Henry McMahon - who, like his ministerial predecessor, Mortimer Durand, would have his own infamous boundary line - acknowledged that the Workman expedition would help to confirm or adjust an earlier survey. Based on the premise that 'We understand the watershed of the Indus to be our boundary and have thought that the Karakoram was that watershed', McMahon then asserted that since the watershed determined the boundary, the government of India was 'not bound to adhere to the Karakoram if it is proved not to be the watershed, but will claim the real watershed as our boundary'. ${ }^{63}$

Further south, the Swedish explorer Sven Hedin was tracing the origins of the Indus watershed in Western Tibet. His discovery in 1907 of the perpendicular so-called 'trans-Himalaya' range complicated Humboldt's purely parallel vision of the Himalayas. In doing so, he noted that the Indus and Brahmaputra watersheds were incongruent with the mountains that were assumed to form a natural, 'scientific' boundary. 'The Trans-Himalaya', Hedin wrote, 'is not only a watershed of the first rank, but is also a geographical boundary of exceptional importance. ${ }^{6}{ }_{4}$ Hedin's discovery came under criticism from subsequent generations of geographers who argued that it was an ill-defined mountain area. If he proved anything, it was that watersheds could cause as much trouble in boundary making as rivers, or any other natural or human-made object.

The decades following MacDonald's and Hedin's revised lines revealed patterns much like those evident in the decades that preceded them: periods of intense interest in boundary making, followed by years of neglect; continued restriction and standardization of maps (including the standardization of map colours and symbols) that eventually produced an agreed upon restricted zone after independence for all trans-border maps; and continued debates between central and regional, and military and civilian administrators, about what should be done to address frontier problems.

\section{IV}

Few terms are as intimately tied to the history of empire as 'frontier'. In a certain sense - from the imperialist's perspective at least - frontier is synecdoche for empire, since it so often carries connotations of expanding territory, uncertain political control, and the violence associated with clashes of 'asymmetric' power. In the British imperial context in India, 'frontier' took on a zonal quality employed to designate ambiguous, or violent, spaces and the limits of political control. By the twentieth century, the frontier had become an idea and a space suffused with security concerns and represented by restricted

63 NAI, Foreign, Frontier B, May 1912, nos. $125^{-6}$. My emphasis.

${ }^{64}$ Sven Hedin, Trans-Himalaya: discoveries and adventures in Tibet, 1 (New York, NY, 1909), p. 273 . 
trans-frontier maps. Borders (or 'boundaries'), in contrast, were meant to mitigate questions of ambiguous control by 'putting a definite edge to the national political horizon, so as to limit unauthorized expansion and trespass'. ${ }^{6}$ But in the northwestern Himalaya - as with other parts of the Himalayan frontier - the natural objects designed to provide a strong and legible border through the vaguely defined frontier space instead produced continued complications. The vastness of the land to be surveyed and mapped, the continued insistence on a legible water-parting line as the northern limit of India, and the increased restriction of 'trans-frontier' information yielded political maps without borders.

A century after Governor General Hardinge requested 'clear and well defined boundaries', the British still lacked a satisfactory border in the northwestern Himalaya. Following independence in 1947, this omission and uncertainty continued on maps and was reflected in intragovernmental communication that included - among other things - the circulation of questionnaires asking local officials for information about the border's exact location. ${ }^{66}$ And in 1962, a Commonwealth Relations Office memo on the 'India-China Border Question' tellingly remarked that 'Survey of India maps issued in 1865, 1903, 1917, 1929, 1936, and 1938 do not show any boundary at all in the western (i.e. Ladakh) sector. ${ }^{67}$ These borderless maps, and those that employed colours and washes to illustrate the same omission, reflected the unwillingness to represent formally territorial ignorance on supposedly precise maps. The Sino-Indian War of 1962 eventually resulted in the imposition of the first effective borderline in the region, the 'Line of Actual Control, which fails to follow the line put forth in the 1899 MacDonald memorandum, the 1865 Johnson Line, or, indeed, the watershed of the Indus. In fact, maps produced in India still fail to show this de facto border, instead maintaining an insistence on the Johnson Line. Legislation was unsuccessfully introduced in 2016 to criminalize maps failing to represent India's claimed border, and a year earlier the government of India banned Al-Jazeera from the air for five days for showing maps that exclude India's claimed territories now occupied by Pakistan and China, a move the government labelled a 'cartographic aggression' ${ }^{68}$

In the British imperial context, the practice of imbuing maps with authority involved transforming terra incognita into colonial territory, a process that oscillated between surveying the land and rendering it on paper. D. Graham Burnett has described how Americans charged with resolving boundary disputes in Guyana went in search of maps and documents in Europe, presuming the

\footnotetext{
${ }_{5}$ 'Frontiers in theory and practice', Geographical Journal, 49 (1917), p. 58 . Emphasis given by the anonymous author of the review of Thomas Holdich's Political frontiers and boundary making (London, 1916).

66 NAI, Ministry of States, $1-\mathrm{K} / 5^{1}$, 'Defence of north-north-east border of Jammu and Kashmir [and] certain aspects of the administration of Ladakh'.

67 National Archives of the United Kingdom, DO 196/19o, 1962. My emphasis.

68 Avaneesh Pandey, 'India bans Al Jazeera for 5 days over "incorrect" Kashmir map', International Business Times, 23 Apr. 2015.
} 
scientific accuracy and the completeness of work done on the ground in the tropics of South America. In appearing to present physicality, cartographic images attempt to settle the political and technological struggles they represent.

The cartographical construction of the northwestern Himalayan frontier was itself an epistemological development of the eighteenth and nineteenth centuries and drew on the work of a number of geographers, most prominently Alexander von Humboldt, 'the scientific traveller par excellence'.$^{69}$ For British surveyors and administrators of the mid-nineteenth century, the naturalness of the great Himalayan barrier could be reinforced through its water partings, which increasingly acted as territorial demarcators and formed the basis of a major principle of international boundary making enshrined in international law by the twentieth century. The rise of cartographical thinking illustrates both the growing authority of colonial (and eventually post-colonial) maps and the evolving logics of border making. Surveying and map making came to represent a vision of a space organized and triangulated through a set of specific technologies of measurement and vision. But the clarity of that vision was often obstructed by complex mountainous landscapes, as was the case in Ladakh and the broader northwestern Himalaya.

The story of mapping the northwestern Himalaya demonstrates that it is important to disaggregate three apparently interwoven aspects of colonial maps as historical sources: first, the representation of land and water rendered on the map from a variety of surveying practices and speculations; second, the lines drawn over that representation to denote political units and their limits (aka territory); and third, the cartographic and geographic rationales used to render and determine the first and the second aspects. While historians of the Himalayan borderland do acknowledge inaccuracies on maps (particularly pre-1899 maps) as sources of disputes arising from these first and second aspects, they tend to ignore the third aspect - the process and the rationale involved in making the land and its supposedly natural boundaries conform to the map.

Paying closer attention to how practices (the rise of the science of surveying, and the coeval rise of the geographical sciences) and products (maps, survey reports, the regular publications of the Royal Geographical Society) worked to facilitate this shift to a more border-centric world can reveal the deeply uneven texture of the process of border making. Such an analysis could not only denaturalize maps, but also denaturalize frontiers and the supposedly natural foundations upon which they were established. The history of the long-elusive border in Ladakh - a boundary supposedly derived from mountain systems and watersheds - offers a perfect test case for such a revision. The production of borderless maps of the northwestern Himalayan region reflected the

${ }^{69}$ Kapil Raj, 'La construction de l'empire de la géographie: L'odyssée des arpenteurs de Sa Très Gracieuse Majesté, la reine Victoria, en Asie centrale', Annales. Histoire, Sciences Sociales, $52 \mathrm{e}$ Année, 5 (Sept.-Oct. 1997), p. 1157. 
simultaneous lack of sufficiently precise information, and an unwillingness to acknowledge that ignorance. It also reflected the unsuccessful application of a geographical concept - the water-parting principle - that was meant to provide a clear means to determining natural and political limits. The nature in natural was all too human. 